\title{
Percutaneous transluminal angioplasty of intracranial artery stenosis: clinical results in 24 patients
}

\author{
Elisabeth Berg-Dammer, M.D., Hans Henkes, M.D., Werner Weber, M.D., Peter Berlit, M.D., Ph.D., and \\ Dietmar Kühne, M.D.
}

Klinik für Neurologie mit Klinischer Neurophysiologie, and Klinik für Allgemeine Röntgendiagnostik und Neuroradiologie, Alfried Krupp Krankenhaus, Essen, Germany

Circumscribed stenotic lesions of the intracranial arteries can cause cerebral ischemia by hemodynamic and/or thromboembolic mechanisms. Anticoagulation therapy, antiplatelet therapy, and bypass surgery are treatment strategies that have no direct impact on the underlying lesion. This study summarizes the experience of a single institution at which percutaneous transluminal angioplasty (PTA) of intracranial atherosclerotic stenoses was performed.

The authors performed a retrospective analysis of 24 consecutive patients. Their medical histories (cardiovascular risk factors, current clinical signs and symptoms and their duration, previous stroke[s], and medical treatment) were evaluated together with findings from previous imaging studies. The site and degree of the stenoses to be treated (target lesion) were identified with the use of ultrasound and angiography studies. Additional vascular stenoses were noted. Percutaneous transluminal angioplasty was performed using single-lumen balloon microcatheters with appropriate diameters. The results of PTA were correlated with angiographic and ultrasound findings and the clinical outcome.

Significant cardiovascular risk factors and clinical signs and symptoms related to the target lesion that persisted despite medical treatment were identified in all patients except one. The duration of symptoms varied from several days to 8 months. Previous stroke had occurred in four patients. The degree of stenosis was classified as "high grade" in 10 patients and as "subtotal" in 14. The target lesion (stenosis) was located in the anterior circulation in eight patients (four in the internal carotid and four in the middle cerebral arteries). Stenoses of posterior circulation vessels were treated in 16 patients (nine vertebral, six basilar, and one posterior cerebral arteries). Recanalization was rated "complete" in 15 patients and sufficient in six patients. In three patients residual stenosis remained. Complications were encountered in seven patients: two asymptomatic dissections, one transient vessel occlusion, one vessel occlusion with subsequent stroke, and three ischemic lesions likely due to thromboembolism, two of which caused only transient neurological symptoms.

Percutaneous balloon dilation proved effective in the treatment of intracranial atherosclerotic stenosis. There are, however, potential complications and experience with this procedure is only limited. Long-term results need to be determined. The authors conclude from their preliminary results that PTA may be an alternative to bypass surgery and conservative management and may be considered for patients in whom ischemic neurological symptoms persist despite medical treatment.

Key Words * atherosclerosis * percutaneous transluminal angioplasty * cerebral ischemia * basilar artery * middle cerebral artery * arterial stenosis 
Percutaneous transluminal angioplasty (PTA) for the treatment of leg arteries was introduced by Dotter and Judkins[10] in 1964, and the principle was later modified and applied to the coronary arteries by Grüntzig, et al.[17] In 1980, Sundt, et al.,[38] performed PTA in stenotic basilar arteries (BAs) after surgical preparation of the vertebral arteries (VAs).

Percutaneous transluminal angioplasty is now widely used in the endovascular treatment of atherosclerotic vascular stenoses of extracranial arteries, including the internal carotid artery (ICA) $[4,11,16,24,41,46]$ and VA.[6,33]

In the last few years only a few reports on PTA for the treatment of intracranial vascular stenoses have been published in the literature. Transfemoral PTA for treatment of intracranial vessels became feasible after the recent development of miniaturized single-lumen balloon catheters. It is our purpose in this article to review our initial experience with this procedure.

\section{CLINICAL MATERIAL AND METHODS}

\section{Patient Population}

Clinical analysis was based on the medical history, recent clinical data, and imaging findings in 24 patients who underwent PTA for treatment of atherosclerotic stenoses of intracranial arteries. Among other variables we recorded cardiovascular risk factors; neurological signs and symptoms, which were finally taken as indication for PTA (medical treatment for these signs and symptoms before PTA, previous strokes, computerized tomography and/or magnetic resonance imaging findings, and location and degree of vascular stenosis to be treated by PTA [target lesion]; additional vascular stenoses and occlusions not to be treated by PTA [nontarget lesions]); anatomical results of PTA; complications of PTA; and short-term clinical outcome after PTA. All patients underwent a thorough neurological examination before, immediately after, and 3 weeks after undergoing PTA. Ultrasound studies including Doppler sonography and color-coded duplex sonography were performed before and after PTA.

\section{Description of PTA Technique}

All procedures were performed in the angiography suite after general anesthesia had been induced in the patient. Through a femoral or axillary approach (one patient), a No. 6 French guiding catheter (Envoy, Cordis, Miami, FL) was inserted into the appropriate ICA or VA. After diagnostic angiography and anticoagulation with heparin had been performed, a working projection was chosen. A FasStealth angioplasty balloon catheter (Target Therapeutics/Boston Scientific, Fremont, CA) was introduced and maneuvered into the stenotic vessel segment. Selection of the maximum balloon diameter and microcatheter guidewire was based on the visual estimation and personal preference of the operator. No efforts were undertaken to measure the diameter of the stenotic target vessel exactly. We did, however, strictly avoid excessive dilation because of the inherent risk of vessel dissection and rupture. Introduction of the guidewire over the stenotic vessel segment was done with maximum care to avoid injury to the vessel wall. In some cases, we found guidewires with hydrophilic coating very helpful because of improved ability to achieve torque. Insertion of the microguidewire 2 to $3 \mathrm{~cm}$ beyond the tip of the balloon catheter provided improved stabilization of the PTA catheter. After positioning the balloon catheter across the stenotic segment, the microcatheter guidewire was withdrawn and replaced by an occlusive valve wire. In angulated vessels, a valve wire with a zero tip (that is, the distal part of the valve wire is not longer than the balloon catheter) was used. If possible, a valve wire with a 1 or $2 \mathrm{~cm}$ tip was preferred. The balloon was very slowly inflated to a maximum of 10 atm under continuous fluoroscopy-guided road-map technique. After 10 to 20 seconds, the balloon was deflated and the catheter removed. In some patients access to the vessel was secured by reintroducing a guidewire distal to the dilated segment in case of dissection and subsequent vessel occlusion. After careful withdrawal of the balloon catheter, a final injection was performed to document the result of the procedure and to ensure patency of the distal territories.

Following the endovascular treatment, blood pressure and vital functions were monitored in all patients in the intensive care unit for at least 24 hours. Anticoagulation therapy with heparin was maintained during the next few 
days until the final decision concerning long-term medical treatment was reached.

\section{RESULTS}

Twenty-four patients (20 men, four women) underwent balloon dilation of atherosclerotic intracranial vascular stenoses. Their demographic data, recent medical histories, clinical findings, imaging findings, and results of therapy in angiographic and clinical terms are summarized in Tables 1 and 2. Angiographic findings pre- and post-PTA are presented casewise in Fig. 1.

\section{TABLE 1}

CLINICAL DATA IN 24 PATIENTS WHO UNDERWENT PTA FOR THE TREATMENT OF INTRACRANIAL YESSELS WITH ATHEROSCLEROTIC STENOSES ${ }^{\star}$

\begin{tabular}{|c|c|c|c|c|c|c|c|}
\hline $\begin{array}{l}\text { Case } \\
\text { No. }\end{array}$ & $\begin{array}{l}\text { Age (ys) } \\
\text { Sex }\end{array}$ & $\begin{array}{c}\text { Cardiovascular } \\
\text { Risk F actors }\end{array}$ & Signs \& Symptoms & $\begin{array}{l}\text { Duration of } \\
\text { Symptorns }\end{array}$ & $\begin{array}{l}\text { Previous } \\
\text { Stroke }\end{array}$ & $\begin{array}{l}\text { Medcal } \\
\text { Therapy }\end{array}$ & Remarks \\
\hline 1 & $77, \mathrm{M}$ & $\ddot{\mathrm{AH}}$ & $\begin{array}{l}\text { progressive It hemi par- } \\
\text { esis, dysarthria, CN } \\
\text { X \& XII paresis }\end{array}$ & 4 mis & none & heparin & SAE \\
\hline 2 & $69, M$ & $\mathrm{AH}, \mathrm{DM}$ & TIA & $\begin{array}{l}\text { Several } \\
\text { days }\end{array}$ & none & tido pidine & $\begin{array}{l}\text { SAE, history of } \\
\text { gastric ulcer }\end{array}$ \\
\hline 3 & $54, M$ & $\mathrm{AH}, \mathrm{HL}, \mathrm{CS}$ & $\begin{array}{l}\text { TIÁ (alternating hem i- } \\
\text { paresis, visual field } \\
\text { deficit, di plopia) }\end{array}$ & $4 \mathrm{mks}$ & none & heparin & none \\
\hline 4 & $68, M$ & $\mathrm{AH}, \mathrm{DM}, \mathrm{HL}$ & It hemi paresis & $6 \mathrm{mks}$ & none & heparin & $\begin{array}{l}\text { neurological deficit } \\
\text { blood pressure } \\
\text { decreased }\end{array}$ \\
\hline 5 & $62, M$ & $\begin{array}{l}\mathrm{AH}, \mathrm{HL} \text {, coro- } \\
\text { nary ysclerosis }\end{array}$ & RIND & $6 \mathrm{mos}$ & none & heparin & SAE \\
\hline 6 & $55, M$ & $\begin{array}{l}\mathrm{AH}, \mathrm{HL}_{1} \text { coro- } \\
\text { nary sclerosis }\end{array}$ & TIA (tt hemiparesis) & $2 \mathrm{mos}$ & none & heparin & \\
\hline 7 & $60, M$ & $\mathrm{AH}, \mathrm{HL}, \mathrm{CS}$ & $\begin{array}{l}\text { TIÁ (diplopia, dysarthria } \\
\text { rt hemi paresis) }\end{array}$ & 2 ws & none & $\begin{array}{c}\text { heparin, } \\
\text { ASA }\end{array}$ & SAE \\
\hline$\stackrel{8}{9}$ & $\begin{array}{l}60, M \\
49, M\end{array}$ & $\begin{array}{l}\mathrm{AH}, \mathrm{HL}, \mathrm{CS} \\
\mathrm{AH}, \mathrm{HL}, \mathrm{CS}\end{array}$ & $\begin{array}{l}\text { It hemianopsia } \\
\text { TIA (diplopia, rotatory } \\
\text { wertigo, perioral } \\
\text { numbness, drop } \\
\text { attacks) }\end{array}$ & $\begin{array}{l}8 \mathrm{mos} \\
4 \mathrm{mos}\end{array}$ & $\begin{array}{l}\text { yes } \\
\text { none }\end{array}$ & $\begin{array}{l}\text { ASÁ } \\
\text { ASÁ }\end{array}$ & SAE \\
\hline 10 & $70, M$ & $\begin{array}{l}\mathrm{AH}, \mathrm{HL}, \text { coro- } \\
\text { nary sclerosis }\end{array}$ & $\begin{array}{l}\text { progressive stroke (t } \\
\text { hemi paresis, It hemi- } \\
\text { ataxia, it CN VI, It CN } \\
\text { IX, It facial hemihypes- } \\
\text { thesia, dysarthria. }\end{array}$ & 2 mks & none & heparin & \\
\hline 11 & $70, M$ & $\mathrm{HL}, \mathrm{DM}$ & $\begin{array}{l}\text { progressive stroke (rt } \\
\text { hemi peresis) }\end{array}$ & 4 mss & yes (2) & heparin & SAE \\
\hline 12 & $70, \mathrm{~F}$ & $\begin{array}{l}\mathrm{AH}, \mathrm{HL}_{1} \text { coro- } \\
\text { nary sclerosis }\end{array}$ & $\begin{array}{l}\text { TIA (para paresis, dip- } \\
\text { lo pia, perioral numb- } \\
\text { ness, anarthria) }\end{array}$ & $6 \mathrm{mos}$ & none & ASA & giant cell arteritis \\
\hline 13 & $36, F$ & none & $\begin{array}{l}\text { TIA, minor stroke (a- } \\
\text { tent It hemiparesis) }\end{array}$ & $8 \mathrm{mos}$ & none & marfarin & \\
\hline 14 & $74, M$ & $\begin{array}{c}\mathrm{AH}, \mathrm{DM}, \mathrm{CS}, \infty \mathrm{r}- \\
\text { onary sclerosis }\end{array}$ & $\begin{array}{l}\text { TIA (diplopia, drop } \\
\text { attacks) }\end{array}$ & $6 \mathrm{mos}$ & none & heparin & SAE \\
\hline 15 & $60, M$ & $\begin{array}{l}\mathrm{AH}_{1} \mathrm{HL}_{1} \text { coronary } \\
\text { soderosis }\end{array}$ & $\begin{array}{l}\text { TIA (diplópia, rotatory } \\
\text { wertigo, perioral } \\
\text { numbness) }\end{array}$ & 3 mks & none & $\begin{array}{l}\text { heparin } \\
\text { TEA }\end{array}$ & status post rt ICA \\
\hline 16 & $50, M$ & $\mathrm{AH}, \mathrm{HL}$ & $\begin{array}{l}\text { TIA (t hemiparesis, } \\
\text { perioral numbness, } \\
\text { dysarthria, dysphagia) }\end{array}$ & $4 \mathrm{mks}$ & none & heparin & \\
\hline 17 & $58, M$ & $\mathrm{AH}, \mathrm{HL}, \mathrm{CS}$ & $\begin{array}{l}\text { TIn (rt paresthesia, } \\
\text { hemi paresis rt) }\end{array}$ & $3 \mathrm{mks}$ & none & heparin & $\operatorname{SAE}$ \\
\hline 18 & $55, \mathrm{~F}$ & $\mathrm{AH}, \mathrm{CS}$ & $\begin{array}{l}\text { stroke (latent rt hemi- } \\
\text { paresis, It ataxia, } \\
\text { dysarthria) }\end{array}$ & $5 \mathrm{mos}$ & yes & heparin & \\
\hline $\begin{array}{l}19 \\
20\end{array}$ & $\begin{array}{l}55, \mathrm{~F} \\
62, \mathrm{M}\end{array}$ & $\begin{array}{l}\mathrm{AH}, \mathrm{HL} \\
\mathrm{AH}, \text { coronary } \\
\text { sderosis }\end{array}$ & $\begin{array}{l}\text { TIA } \\
\text { asym ptomatic }\end{array}$ & $\frac{2 \operatorname{mos}}{-}$ & $\begin{array}{l}\text { none } \\
\text { none }\end{array}$ & $\begin{array}{l}\text { heparin } \\
\text { ASÁ }\end{array}$ & PTÁ prior to ACVB \\
\hline 21 & $67, M$ & $\mathrm{HL}$ & $\begin{array}{l}\text { progressive stroke } \\
\text { (tt hemiparesis) }\end{array}$ & $3 \mathrm{mks}$ & none & heparin & SAE \\
\hline 92 & $58 \mathrm{M}$ & $\mathrm{HI} \mathrm{CS}$ & TIü risearthria reri- & 4 ink s & inse & herarin & \\
\hline
\end{tabular}




\begin{tabular}{|c|c|c|c|c|c|}
\hline $67, M$ & $\mathrm{HL}, \mathrm{DM}$ & TIÁ (nausea, di plopia) & $4 m k s$ & none & $\begin{array}{l}\text { marfarin } \\
\text { ASA }\end{array}$ \\
\hline $70, M$ & $\mathrm{AH}, \mathrm{HL}, \mathrm{DM}$ & $\begin{array}{l}\text { TIÁ (hemiparesis, } \\
\text { aphasia) }\end{array}$ & 4 mks & none & heparin \\
\hline
\end{tabular}

"Abtre viations: $\mathrm{ACVB}=$ arteriocoronary tenous bypass; $\mathrm{AH}=$ arterial hypertension; $\mathrm{ASA}=$ acetyl salicylic acid; $\mathrm{CCA}=\mathrm{Com}-$ mon carotid artery, $\mathrm{CN}=\mathrm{cranial}$ ner we palsy; $\mathrm{CS}=$ cigarette smoking; $\mathrm{DM}=$ diabetes mellitus; $\mathrm{HL}=$ hyperli pidemia; LIF = local in traarterial fitrinol ysis; RIND = reversible ischemic neurological deficit; $8 \mathrm{AE}$ = subcortical atherosclerotic encephalopathy, TEA $=$ thromboendarterectomy.

Patient age ranged from 36 and 77 years (mean $61.5 \pm 9.3$ years, median 61 years). All patients except one had at least one cardiovascular risk factor. Recurrent transient ischemic attacks (TIAs) (15 patients) and progressive stroke (five patients) were the most frequent indications for PTA. In one asymptomatic patient, treatment was performed at the surgeon's request as a prophylactic measure before cardiac bypass surgery. Duration of the current symptoms ranged between 2 days and several months. Four patients had previously experienced a complete stroke prior to the PTA. Twenty-three patients were not free of ischemic symptoms despite receiving heparin (16 patients), acetyl salicylic acid (four patients), ticlopidine (one patient), warfarin (one patient), or a combination of two substances (two patients).

TABLE 2

RAD OLOGICAL FIND NGS AND RESULTS IN 24 PATIENTS WHO UNDERWENT PTA FOR THE TREATMENT OF INTRACRANIAL YESSELS WITH ATHEROSCLEROTIC STENOSES ${ }^{\star}$

\begin{tabular}{|c|c|c|c|c|c|c|}
\hline $\begin{array}{l}\text { Case } \\
\text { No. }\end{array}$ & $\begin{array}{l}\text { Locali on of Isch- } \\
\text { emic Lesionst }\end{array}$ & $\begin{array}{l}\text { Location \& De- } \\
\text { gree of Stenosis }\end{array}$ & Angiogapric Findings & $\begin{array}{l}\text { Degee of } \\
\text { Recanalization } \\
\text { Post-PTA }\end{array}$ & $\begin{array}{l}\text { Compli- } \\
\text { cations }\end{array}$ & $\begin{array}{l}\text { Early Clinical } \\
\text { Outcome }\end{array}$ \\
\hline 1 & medulla & $\begin{array}{l}\text { It } V_{\text {A }}\left(V_{4}\right) \text { high } \\
\text { grade }\end{array}$ & rt VA occlusion & sufficient & none & im proved \\
\hline 2 & none & It M̆CA high grade & $\begin{array}{l}\text { It } V_{A}\left(V_{1}\right) \text { stenosis, rt ICA } \\
\& \text { MCA minor stenosis }\end{array}$ & complete & none & asym ptomatic \\
\hline 3 & $\begin{array}{l}\text { pons } \& \text { rt cere- } \\
\text { bellum }\end{array}$ & It $V_{A}\left(V_{4}\right)$ subtotal & $\begin{array}{l}\text { rt VA ocolusion, rt MCA > } \\
\text { It stenotic }\end{array}$ & $\begin{array}{l}\text { residual } \\
\text { stenosis }\end{array}$ & none & asym ptomatic \\
\hline 4 & rt parie tal & $\underset{t=l}{\mathrm{rt}} \mathrm{ICA}_{(\mathrm{I}}\left(\mathrm{C}_{3}\right)$ subto- & $\begin{array}{l}\text { rt \& It } V_{A}\left(V_{1}\right) I C A\left(C_{3}\right) \\
\text { minor stenoses }\end{array}$ & complete & none & im proved \\
\hline 5 & none & rt $\underset{t=1}{I C A}\left(C_{1}\right)$ subto- & rt ICA cervical & complete & RIND & $\begin{array}{l}\text { worse, } \\
\text { hemi paresis }\end{array}$ \\
\hline 6 & rt frontil & $\begin{array}{l}\text { rt MCA }\left(M_{1 / 2}\right) \\
\text { high grade }\end{array}$ & none & complete & TIAS & asym ptomatic \\
\hline 7 & none & BÁ caudal subtotal & rt $V_{A}\left(V_{1}\right)$ minor stenosis & complete & $\begin{array}{l}\text { transient } \mathrm{BA} \\
\text { ocdusion }\end{array}$ & asym ptomatic \\
\hline 8 & $\begin{array}{l}\text { temporal } \& \mathrm{rt} \\
\text { parietal }\end{array}$ & $\begin{array}{l}\text { rt VA }\left(\mathrm{V}_{3 / 4}\right) \text { high } \\
\text { grade }\end{array}$ & $\begin{array}{l}\text { It stenoses, MCA It ICA, It } \\
\text { PCA, It CCA; rt CCA oc- } \\
\text { clusion; It VÁ hypoplasia. }\end{array}$ & complete & none & unchanged \\
\hline 9 & none & It $V_{A}\left(V_{4}\right)$ & rt VÁ ocolusion & complete & none & asymptomatic \\
\hline 10 & $\begin{array}{l}\text { rt cerebellum, } \\
\text { pons }\end{array}$ & $\begin{array}{l}\text { BÁ caudal high } \\
\text { grade }\end{array}$ & general atherosderosis & sufficient & none & im proved \\
\hline 11 & $\begin{array}{l}\text { frontal \& It } \\
\text { perietal }\end{array}$ & It $\mathrm{m}_{\mathrm{tal}} \mathrm{CA}\left(\mathrm{M}_{1}\right)$ subto- & $\begin{array}{l}\text { rt MCA stenosis general } \\
\text { atherosderosis }\end{array}$ & sufficient & none & im proved \\
\hline 12 & none & It $V_{A}\left(V_{4}\right)$ subtotal & rt VA hypoplastic & complete & dissection & asymptomatic \\
\hline 13 & rt frontal & rt ICA $\left(C_{1}\right)$ subtotal & none & complete & none & im proved \\
\hline 14 & none & rt VA $\left(V_{4}\right)$ high grade & $\begin{array}{l}\text { It VA \& It ICA ocdusion, } \\
\text { rt ICA stenosis }\end{array}$ & sufficient & none & asym ptomatic \\
\hline 15 & none & rt VA $\left(V_{4}\right)$ subtotal & It VA h ypoplasia \& stenosis & complete & none & asym ptomatic \\
\hline 16 & none & $\begin{array}{l}\text { midbasilar high } \\
\text { grade }\end{array}$ & $\begin{array}{l}\text { It VA occlusion general } \\
\text { atherosderosis }\end{array}$ & complete & none & asym ptomatic \\
\hline 17 & none & It $\mathrm{PCA}_{\text {total }}\left(\mathrm{P}_{1 / 2}\right)$ sub- & general atherosderosis & $\begin{array}{l}\text { residual } \\
\text { stenosis }\end{array}$ & $\begin{array}{l}\text { PCA ocdu- } \\
\text { sion, LIF, } \\
\text { infarct }\end{array}$ & $\begin{array}{l}\text { worse, hemi pa- } \\
\text { resis \& hemi- } \\
\text { anopsia. }\end{array}$ \\
\hline 18 & pons & $\begin{array}{l}\text { midbasilar high } \\
\text { grade }\end{array}$ & none & complete & none & im proved \\
\hline 19 & none & BÄ caudal subtotal & $\begin{array}{l}\text { It } \mathrm{MCA}, \text { it } \& \text { It PCA } \\
\text { stenoses }\end{array}$ & sufficient & none & asym ptomatic \\
\hline 20 & $\begin{array}{l}\text { pons, It basal } \\
\text { ganglia. }\end{array}$ & rt VA $\left(V_{4}\right)$ subtotal & $\begin{array}{l}\text { It VA h ypoplasia, rt VA }\left(V_{1}\right) \\
\text { stenosis It ICA stenosis }\end{array}$ & complete & none & asym ptomatic \\
\hline$n$ & & 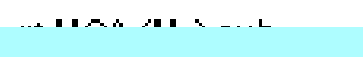 & & - - - & $\ldots \ldots$ & $:-\ldots . . .$. \\
\hline
\end{tabular}




\begin{tabular}{|c|c|c|c|c|c|c|}
\hline 21 & $\begin{array}{l}\text { rt casaj } \\
\text { aanolia }\end{array}$ & ri mü $\left(m_{1}\right)$ sud & none & comprete & none & Im proved \\
\hline 22 & $\begin{array}{l}\text { It occipital, rt } \\
\text { thalamus, } \\
\text { It pons }\end{array}$ & $\begin{array}{l}\text { rt } \mathrm{VA}_{\mathrm{A}}\left(\mathrm{V}_{4}\right) \text { high } \\
\text { grade }\end{array}$ & $\begin{array}{l}\text { It VA occlusion, It ICA } \\
\text { stenosis }\end{array}$ & complete & none & asym ptomatic \\
\hline 23 & none & BÁ caudal subtotal & none & $\begin{array}{l}\text { residual } \\
\text { stenosis }\end{array}$ & ischemia & $\begin{array}{l}\text { morse, hemipa- } \\
\text { resis \& train- } \\
\text { stem infarct }\end{array}$ \\
\hline 24 & none & It ICA $\left(\mathrm{C}_{5}\right)$ subtotal & rt CCA stenosis & sufficient & dissection & asymptomatic \\
\hline
\end{tabular}

Pretreatment imaging with computerized tomography and/or MR imaging revealed no definitive ischemic lesion in 12 patients who had a history of transient cerebral ischemia. With one exception ischemic lesions in the other 12 patients were located in areas of the brain that were supplied by the stenotic artery to be treated. The target lesion for the PTA procedure was located at the intracranial VA nine patients, the basilar artery (BA; six patients), middle cerebral artery (MCA; five patients), and the posterior cerebral artery (PCA) $\mathrm{P}_{1}$ segment (one patient). The stenoses were high grade in 10 patients and subtotal in 14. Four-vessel angiography revealed additional stenoses or vessel occlusions in all but four patients. In 15 patients, PTA completely dilated the stenotic vessel. The dilation was sufficient in six cases. In three patients significant stenosis remained. No complications occurred in 17 patients. Complications included two asymptomatic arterial wall dissections, two transient cerebral ischemias, two vessel occlusions (one transient and asymptomatic, one permanent and causing a stroke), and one brainstem infarct. All ischemic complications occurred directly after the procedure. At discharge, 13 patients were neurologically asymptomatic. It is noteworthy that one of these patients (Case 3), who had previously suffered from brainstem TIAs with alternating hemiparesis, visual field deficits, and diplopia, still had a significant but now asymptomatic residual stenosis of the dilated VA. Seven patients were neurologically improved but not free of preexisting symptoms. One patient with hemianopsia caused by a previous stroke remained unchanged. The high-grade stenoses of his VA had been completely dilated. 


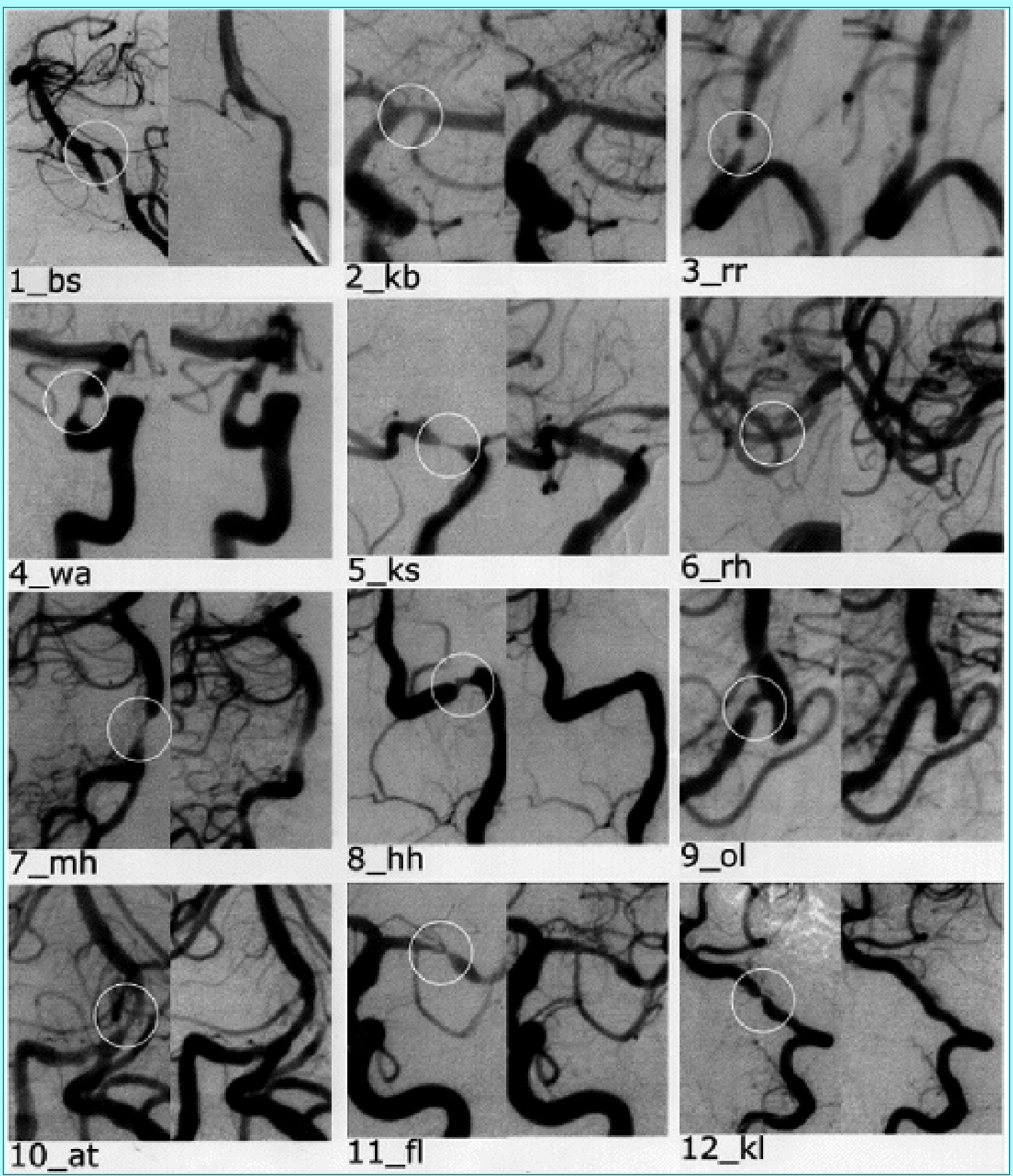




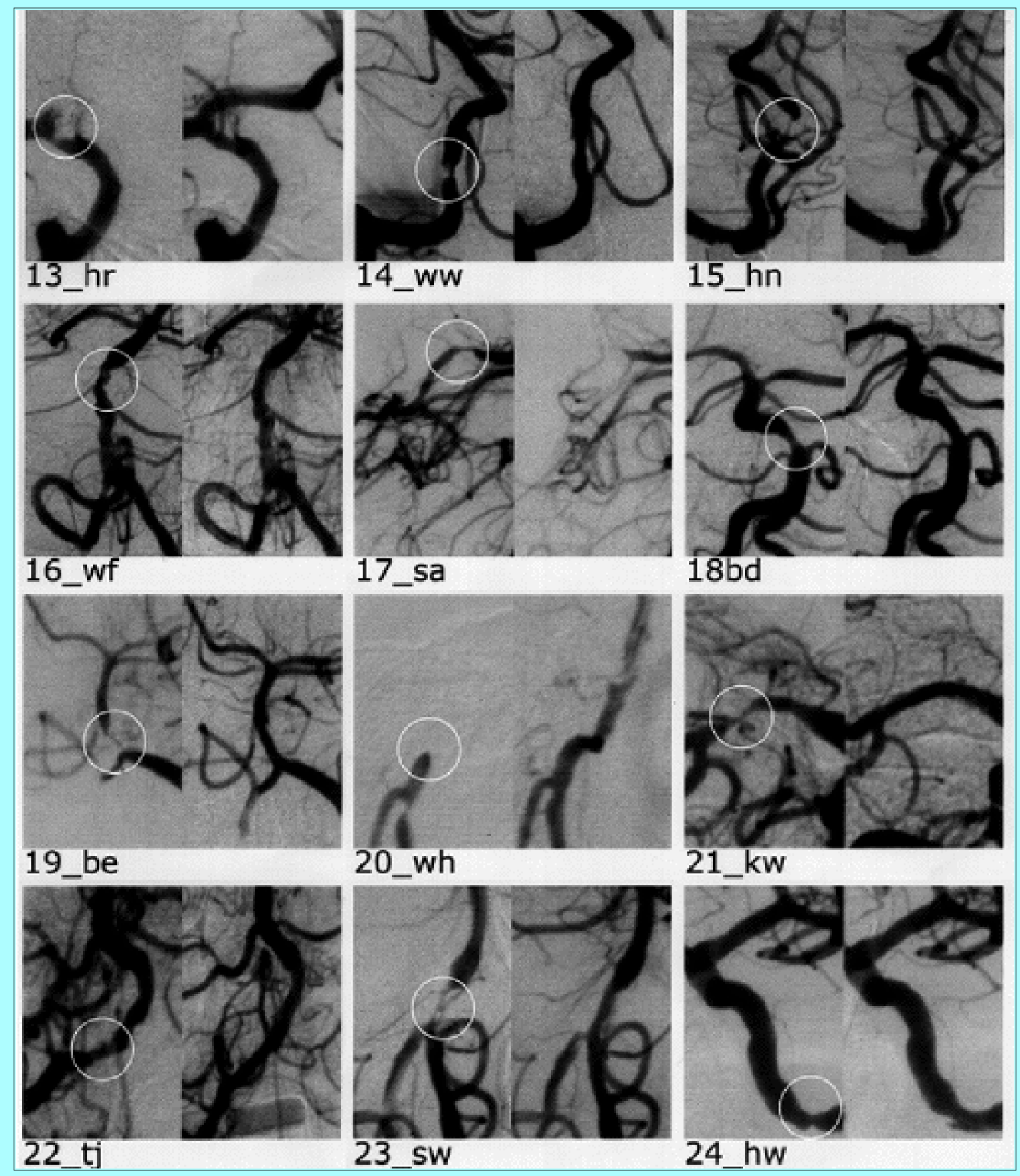

Fig. 1. Cases 1 through 24. a and b: Digital subtraction angiograms in 24 patients with atherosclerotic intracranial vascular stenoses. Each case is illustrated by corresponding magnified angiographic views prior to (left) and after (right) PTA.

Clinical symptoms in three patients worsened following PTA. Hemiparesis due to a thromboembolic complication during PTA was encounterd in one patient (Case 5). In another patient (Case 17), occlusion of the PCA during PTA caused hemiparesis and hemianopsia. In one patient (Case 23), dilation of a subtotally stenosed BA caused injury to perforating branches or thromboembolism that led to a nondisabling brainstem infarct 4 hours after the procedure. In these three patients, MR imaging showed ischemic lesions at the site of the dilated vessel.

\section{DISCUSSION}

Clinicians treating TIAs in intracranial vessel occlusive disease have several therapeutic options. Pharmacological antiplatelet or anticoagulation therapy is currently considered the treatment of choice.[12,14,36,47] If this regimen 
fails, extracranial-intracranial bypass surgery may be considered in selected patients. This is, however, a surgical procedure with unavoidable morbidity and mortality rates.[21] Intracranial PTA for treatment of atherosclerotic stenoses has now become a third option.

Percutaneous transluminal angioplasty for treatment of intracranial vessels requires a balloon catheter system sufficiently flexible to pass through tortuous vasculature. The exact transmission of axial forces is crucial for a correct placement of the balloon. In an open-ended system it is preferable to use a steerable guidewire and to inject contrast medium through the PTA catheter during the procedure. All these criteria are met by the FasStealth dilation system. The advantages of this device compared with previous systems have been described by Bracard, et al.[5]

Percutaneous transluminal angioplasty for treatment of intracranial vessels may be considered in patients whose neurological symptoms recur or progress despite adequate medical treatment. The aim of this procedure is primarily to improve blood flow in the brain region supplied by the target vessel, which can be achieved by a 50\% dilation. This degree of dilation has been recommended to avoid vessel rupture.[1] Early restenosis, which is more likely under such conditions, may be acceptable if the transient dilation effect avoids ischemia by providing time for collateral branches to enlarge.

Complications of PTA for the treatment of intracranial atherosclerotic stenoses include vessel rupture, $[19,28]$ acute vessel occlusion,[9] delayed rupture after development of a pseudoaneurysm,[38] and delayed vessel occlusion.[1] It is not known whether hyperperfusion injury occurs after the dilation of intracranial vascular stenoses.[37]

Several measures can help to prevent vessel injury. Induction of general anesthesia with complete immobilization of the patient is essential for precision of the entire procedure. This precludes clinical monitoring. We found it sufficient to rely on the data obtained from angiography, without additional neurophysiological monitoring. During the procedure, systemic anticoagulation therapy with heparin is strongly recommended to avoid thromboembolic complications. Subsequent antiplatelet therapy combined with heparin for several days can help to avoid deposition of platelets and fibrin on the endothelium, which is altered by PTA. Balloon dilation causes changes in the endothelium and lamina media.[48] The degree of injury to the vessel wall seems to be related to the time of balloon inflation.[8] Thus, we limited balloon inflation to 30 seconds.

During the period immediately after the procedure, monitoring of blood pressure and cerebral blood flow (by means of transcranial Doppler ultrasonography) is crucial. Arterial blood pressure should be maintained in the upper range of normal for approximately 3 days. If high-intensity transient signals are recorded distal to the dilated vessel we start the patient on a course of anticoagulant therapy. Using this regimen, we observed no additional clinical deterioration during the early post-PTA period.

\section{Review of the literature}

Only a limited number of studies have been published on the clinical results of PTA for the treatment of intracranial vessels. We evaluated the literature and identified the numbers of treated patients, the sites and anatomical success of PTA, and the clinical results and complications. Interesting aspects of the indication, mode of treatment, and follow-up results were noted.

Sundt, et al.,[38] are credited with the introduction of PTA of intracranial vessels. In 1980, this group successfully dilated high-grade, symptomatic BA stenoses in two patients by using coronary angioplasty catheters after surgical exposure of the VA at its $\mathrm{V}_{3}$ segment.

Purdy, et al.,[35] have used a soft silicone balloon catheter for dilation of a symptomatic left MCA stenosis in a procedure that was complicated by severe vasospasm immediately after PTA. Restenosis occurred on Day 5. Nevertheless, the patient improved clinically and single-photon emission computerized tomography studies showed improved regional cerebral blood flow.

Ahuja, et al.,[1] succeeded in performing PTA for the treatment of a symptomatic stenosis of the midbasilar segment in a 68-year-old man, who had only minor transient neurological symptoms during the early follow-up 
phase. The dilated vessel was found to be occluded 6 months after the procedure. The patient remained asymptomatic during the following 2 years.

Touho, et al.,[43] performed intracranial PTA during the acute phase of ischemic stroke in their patient. An MCA stenosis and $\mathrm{V}_{4}$ stenosis were dilated 6 and 7 days, respectively, after onset of acute stroke in two patients, who improved significantly. The same group reported on the balloon dilation of a symptomatic stenosis of the PCA. Touho, et al.,[42] attempted PTA in the anterior circulation in 19 patients and finally performed it in 13 patients, (two $\mathrm{C}_{5}$ segments of the ICA; three $\mathrm{C}_{4}$ segments of the ICA; three $\mathrm{C}_{2}$ segments of the ICA; six $\mathrm{M}_{1}$ segements of the ICA; three $\mathrm{M}_{2}$ segments of the ICA; and two $\mathrm{A}_{2}$ segments of the anterior cerebral arteries). Only seven of 13 patients improved after intracranial PTA. The mean degree of stenosis measured was $83 \%$ before PTA, $25 \%$ immediately after, and $36 \%$ on follow-up angiography. In five of 13 patients restenosis was seen on follow-up examination more than 6 months after PTA. The reported complications were one asymptomatic vessel dissection and two transient aggravations of preexisting hemiparesis.

Marks, et al.,[28] have reported on the results of 18 patients who underwent intracranial PTAs (six ICA, eight VA, two MCA, and two BA). Balloon dilation was successful in 15 cases. In two patients the stenotic vessel segment was not dilated, and one vessel ruptured during PTA. In one of three fatal outcomes, death resulted from the procedure. In 11 patients, follow-up angiography showed no residual stenosis. One vessel was found to be occluded. No new or recurrent ischemic symptoms occurred during a mean follow-up period of 12 months. The updated results of this group were even better.[29] During the long-term follow-up period of 7 to 72 months (mean 31 months) in 20 patients, one patient developed a stroke in the region dependent on the PTA site and one patient suffered a stroke in a region unrelated to the treated vessel.

Clark, et al.,[9] dilated 22 intracranial vessels in 17 patients, which included 11 VAs, five BAs, four ICAs, and two MCAs. The mean reduction of vessel stenosis was estimated as $43 \%$. The radioanatomical results in eight patients who underwent 6-month follow-up angiography were even better. All patients who underwent uneventful PTA showed resolution of previous symptoms with no further TIAs at 6 months. No strokes occurred in the territory of the treated artery during a mean 22 months of long-term follow up (maximum 54 months). In this series no vessel rupture or death was observed. Two patients, however, had strokes associated with PTA: one was due to dissection and subsequent occlusion of an MCA; and in the other patient, a pontine infarct was thought to result from penetrating branch occlusion during dilation of a BA stenosis. Kellogg, et al.,[25] have presented an updated report on the experience of their group: at that time 34 vessels in 27 patients had been treated. The mean degree of stenosis was reduced from $72 \%$ to $46 \%$. During a mean follow-up period of 28 months, 16 patients remained symptom-free. One minor and two major strokes occurred during PTA. Five patients died: two deaths were periprocedural and due to the disease at presentation, two from other causes during the follow-up period, and one from stroke referable to the treated vascular territory.

Higashida et al.,[18] have extensive experience with PTA for the treatment of supraaortic and intracranial vessels and have reported on the intracranial PTA treatment of stenoses affecting the MCA in seven cases, the VA in eight cases, and the BA in three patients. Four of these patients had transient cerebral ischemia and six suffered a procedure-related stroke, resulting in three fatalities. Six of their patients are also included in the series of Terada, et al.,[40] whose group reported their results of intracranial PTA treatment of the posterior circulation in 12 patients. In four patients the residual stenosis after PTA was greater than 50\%. The three survivors of this subgroup, however, remained without new symptoms during follow-up periods of 4, 4, and 1.4 years, respectively. During the mean follow-up period of 24 months, 10 patients had no recurrence of ischemic symptoms originating in the posterior circulation. Repeated angiography was performed in seven patients and revealed one symptomatic and one asymptomatic restenosis after 6 months. Two embolic infarctions caused transient neurological deficits. Two acute vessel occlusions due to dissection resulted in a permanent neurological deficit in one patient and caused fatal brainstem infarction in the other.

Houdart, et al.,[22] reported the dilation of a tight midbasilar stenosis with almost complete restoration of the vessel lumen and excellent clinical improvement. 
In two of 47 intracranial PTA procedures, Berger, et al.,[3] reported two fatal vessel ruptures and one minor stroke. Hyodo,et al.,[23] treated 38 intracranial stenoses in 36 patients by PTA (15 MCA, 13 ICA, six BA, and four VA), and treatment was successful ( $<50 \%$ residual stenosis) in 34 of 41 procedures. One major and two minor strokes occurred. Follow-up angiography in 28 cases revealed recurrent stenosis in five patients and vessel occlusion in one. During a 1-year clinical follow-up period in 27 patients no TIAs or stroke occurred.

Mori, et al.,[31] have proposed a morphological classification of intracranial vascular stenoses. Type A lesions are short ( $<5 \mathrm{~mm}$ in length), concentric or only moderately eccentric, smooth, not calcified, do not involve a major branch, do not carry a thrombus and are nonangulated. Type B lesions are longer (5-10 $\mathrm{mm}$ ), eccentric, distal to moderately tortuous vessels, moderately angulated $\left(45 \mathrm{~s}\right.$ to $\left.<90^{\circ}\right)$, show an irregular contour, are calcified and/or carry a thrombus, and may be located at a bifurcation. Total occlusion for less than 3 months is also classified as a Type B lesion. The Type $\mathrm{C}$ lesion is even longer $(>1 \mathrm{~cm})$, distal to excessively tortous vessels, angulated $\left(>90^{\circ}\right)$, and side branches cannot be protected. Total occlusion for more than 3 months is also classified as a Type $\mathrm{C}$ lesion. Between 1992 and 1994, this group tried to dilate 35 intracranial arterial stenoses (20 MCA, nine ICA, three VA, two PCA, one BA). The attempt failed in eight cases. Major complications were one symptomatic dissection of the ICA, one stroke due to acute occlusion of the MCA, and one fatal MCA rupture. Follow-up angiography revealed restenosis in three of six ICA lesions and five of $16 \mathrm{MCA}$ lesions. These eight recurrent stenoses were again treated by PTA. Angiography 12 months after PTA showed no restenosis in any case that had been free from vessel narrowing at 3 months. These remaining 19 patients had no ischemic neurological symptoms during the follow-up period. The same group also succeeded in reopening four of six totally occluded MCAs.[32] In an update of their results, the clinical success rates for PTA were 92\%, 86\%, and 33\% for Type A, B and C lesions, respectively (unpublished data). The restenosis rates at 1 year were $0 \%, 33 \%$, and $100 \%$ for Type $\mathrm{A}, \mathrm{B}$, and $\mathrm{C}$ lesions, respectively.

During the last few years, several articles and case reports have focused on technical details of intracranial PTA or individual features of the reported case.

In a patient treated by Touho, et al.,[44] vertebrobasilar insufficiency was caused by a stenotic primitive hypoglossal artery that was successfully dilated.

Even the reopening of occluded intracranial vessels appears technically feasible. Honda, et al.,[20] reported their experience of recanalizing a short $\mathrm{V}_{4}$ segment in a patient with bilateral occlusion of the VAs. Vertebrobasilar symptoms had resulted from poor collateralization to the posterior circulation.

Miyachi, et al.[30] performed balloon dilation of an MCA stenosis in a patient who underwent stent placement in an ipsilateral ICA following traumatic vessel dissection. The authors interpret the MCA lesion as an atherosclerotic stenosis. Because this patient's neurological deficit coincided with the vessel injury, it would seem difficult to decide whether the underlying mechanism was hemodynamic or thromboembolic. To judge from the available data, the stenosis to be dilated might also have been the sequel of a previous embolus.

In certain cases with atherosclerotic stenosis and associated thrombotic vessel occlusion, balloon dilation may be an optional and promising adjunct to local intraarterial fibrinolysis.[40, 45]

\section{CONCLUSIONS}

Our experience is consistent with the most recent reports on this issue. The criteria for patient selection, indication, the technique and device use are much the same as described by most authors. It may be noted that only a few other single-institution groups have treated more patients. Our series is characterized by the high percentage of PTA procedures in the posterior circulation. It is also noteworthy that no death and debilitating stroke were encountered in this series. The long-term results, both clinical and angiographic, will be most important. All patients in this series are being seen regularly in our outpatient department and will undergo follow-up angiography. 
To date we have, with one exception, treated symptomatic intracranial stenoses by PTA. The general reluctance to dilate asymptomatic stenoses is mainly due to the fact that fatal complications of balloon dilation of intracranial vessels have been reported by several authors.[3,18,25,27,39] However, intracranial atherosclerotic lesions have a strong tendency to progress, and the chance of spontaneous regression is only limited.[2] Preexisting stenosis is frequently found both in the anterior and posterior circulation in patients with occlusive thrombosis. $[7,15,26,34]$

The absence of ulceration and calcification of atherosclerotic cerebral arteries distal to the siphon and above the origin of the posterior inferior cerebellar artery[13] indicates that arterioarterial embolism is not the major cause of ischemic stroke in patients with intracranial stenosis, and may explain the frequent failure of antiplatelet and anticoagulation therapies. Hemodynamic changes are the main factor in the development of cerebral ischemic events. A therapeutic dilemma does arise: it is necessary to use antihypertensive drugs to avoid a progression of the atherosclerotic disease; however, lowering the systemic blood pressure below the critical threshold required for sufficient perfusion distal to an intracranial stenosis will provoke symptomatic brain ischemia. The histological features of intracranial vessel stenoses are an argument in favor of the feasability of balloon dilation.

If further studies prove PTA for the treatment of the intracranial arteries safe and effective, this procedure may in future become a therapeutic option for patients with progressive stenoses, even when anticoagulation therapy is successful in preventing a symptomatic manifestation of the vascular stenosis.

\section{References}

1. Ahuja A, Guterman LR, Hopkins LN: Angioplasty for basilar artery atherosclerosis. Case report. J Neurosurg 77:941-944, 1992

2. Atkins PT, Pilgram TK, Cross DW, et al: Natural history of stenosis from intracranial atherosclerosis by serial angiography. Stroke 29:433-438, 1998

3. Berger BL, Callahan AS: Balloon angioplasty for stroke prevention: results in 73 cases. Intervent Neuroradiol 3 (Suppl 1):37, 1997(Abstract)

4. Bockenheimer SA, Mathias K: Percutaneous transluminal angioplasty in arteriosclerotic internal carotid artery stenosis. AJNR 4:791-792, 1983

5. Bracard S, Picard L, Marchal JC, et al: Intérêt de l'angioplastie dans le traitement du vasospasme symptomatique post-opératoire des anévrysmes intra-craniens rompus. J Neuroradiol 17:6-19, 1990

6. Brückmann H, Ringelstein EB, Buchner H, et al: Percutaneous transluminal angioplasty of the vertebral artery. A therapeutic alternative to operative reconstruction of proximal vertebral artery stenoses. J Neurol 233:336-339, 1986

7. Castaigne P, Lhermitte F, Gautier JC, et al: Arterial occlusions in the vertebro-basilar system. A study of 44 patients with post-mortem data. Brain 96:133-154, 1973

8. Chàvez L, Takahashi A, Yoshimoto T, et al: Morphological changes in normal canine basilar arteries after transluminal angioplasty. Neurol Res 12:12-16, 1990

9. Clark WM, Barnwell SL, Nesbit G, et al: Safety and efficacy of percutaneous transluminal angioplasty for intracranial atherosclerotic stenosis. Stroke 26:1200-1204, 1995

10. Dotter CT, Judkins MP: Transluminal treatment of arteriosclerotic obstruction. Description of a new technic and a preliminary report of its application. Circulation 30:654-670, 1964

11. Eckert B, Zanella FE, Thie A, et al: Angioplasty of internal carotid artery: results, complications and follow-up in 61 cases. Cerebrovasc Dis 6:97-105, 1996 
12. Estol CJ, Pessin MS: Anticoagulation: is there still a role in atherothrombotic stroke? Stroke 21:820-824, 1990

13. Fisher CM, Gore I, Okabe N, et al: Atherosclerosis of the carotid and vertebral arteries: extracranial and intracranial. J Neuropathol Exp Neurol 24:455-476, 1965

14. Gårde A, Samuelsson K, Fahlgren H, et al: Treatment after transient ischemic attacks: a comparison between anticoagulant drug and inhibition of platelet aggregation. Stroke 14:677-681, 1983

15. George B, Laurian C: Vertebro-basilar ischaemia. Its relation to stenosis and occlusion of the vertebral artery. Acta Neurochir 62:287-295, 1982

16. Gil-Peralta A, Mayol A, Marcos JR, et al: Percutaneous transluminal angioplasty of the symptomatic atherosclerotic carotid arteries. Results, complications, and follow-up. Stroke 27:2271-2273, 1996

17. Grüntzig AR, Senning A, Siegenthaler WE: Nonoperative dilatation of coronary-artery stenosis: percutaneous transluminal coronary angioplasty. N Engl J Med 301:61-68, 1979

18. Higashida RT, Tsai FY, Halbach VV, et al: Interventional neurovascular techniques in the treatment of stroke--state-of-the-art therapy. J Intern Med 237:105-115, 1995

19. Higashida RT, Tsai FY, Halbach VV, et al: Transluminal angioplasty for atherosclerotic disease of the vertebral and basilar arteries. J Neurosurg 78:192-198, 1993

20. Honda S, Mori T, Fukuoka M, et al: Successful percutaneous transluminal angioplasty of the intracranial vertebral artery 1 month after total occlusion--case report. Neurol Med Chir 34:551-554, 1994

21. Hopkins LN, Budny JL: Complications of intracranial bypass for vertebrobasilar insufficiency. J Neurosurg 70:207-211, 1989

22. Houdart E, Ricolfi F, Brugières P, et al: Percutaneous transluminal angioplasty of atherosclerotic basilar artery stenosis. Neuroradiology 38:383-385, 1996

23. Hyodo A, Matsumaru Y, Anno I, et al: Percutaneous transluminal angioplasty for atherosclerotic stenosis of the intracranial cerebral arteries. Results with more than one year follow up. Intervent Neuroradiol 3 (Suppl 1):38, 1997 (Abstract)

24. Kachel R, Basche S, Heerklotz I, et al: Percutaneous transluminal angioplasty (PTA) of supra-aortic arteries especially the internal carotid artery. Neuroradiology 33:191-194, 1991

25. Kellogg J, Nesbit GM, Clark W, et al: Percutaneous transluminal angioplasty for intracranial atherosclerotic stenosis: long term follow-up. Intervent Neuroradiol 3 (Suppl 1):39, 1997 (Abstract)

26. Lhermitte F, Gautier JC, Derouesné C: Nature of occlusions of the middle cerebral artery. Neurology 20:82-88, 1970

27. Linskey ME, Horton JA, Rao GR, et al: Fatal rupture of the intracranial carotid artery during transluminal angioplasty for vasospasm induced by subarachnoid hemorrhage. Case report. J Neurosurg 74:985-990, 1991

28. Marks M, Norbash A, Clark J, et al: Angioplasty of intracranial circulation stenosis. Stroke 26:159, 1995 (Abstract)

29. Marks MP, Marcellus ML, Norbash AN, et al: Evaluation of long term clinical outcome in patients undergoing intracranial angioplasty. Intervent Neuroradiol 3 (Suppl 1):38, 1997 (Abstract)

30. Miyachi S, Ishiguchi T, Taniguchi K, et al: Endovascular stenting of a traumatic dissecting aneurysm of the extracranial internal carotid artery--case report. Neurol Med Chir 37:270-274, 1997 
31. Mori T, Mori K, Fukuoka M, et al: Percutaneous transluminal angioplasty for total occlusion of middle cerebral arteries. Neuroradiology 39:71-74, 1997

32. Mori T, Mori K, Fukuoka M, et al: Percutaneous transluminal cerebral angioplasty: serial angiographic follow-up after successful dilatation. Neuroradiology 39:111-116, 1997

33. Motarjeme A, Keifer JW, Zuska AJ: Percutaneous transluminal angioplasty of the brachiocephalic arteries. AJR 138:457-462, 1982

34. Moufarrij NA, Little JR, Furlan AJ, et al: Basilar and distal vertebral artery stenosis: long-term follow-up. Stroke 17:938-942, 1986

35. Purdy PD, Devous MD Sr, Unwin DH, et al: Angioplasty of an atherosclerotic middle cerebral artery associated with improvement in regional cerebral blood flow. AJNR 11:878-880, 1990

36. Sandercock PAG, van den Belt AGM, Lindley RI, et al: Antithrombotic therapy in acute ischaemic stroke: an overview of the completed randomised trials. J Neurol Neurosurg Psychiatry 56:17-25, 1993

37. Schoser BGH, Heesen C, Eckert B, et al: Cerebral hyperperfusion injury after percutaneous transluminal angioplasty of extracranial arteries. J Neurol 244:101-104, 1997

38. Sundt TM Jr, Smith HC, Campbell JK, et al: Transluminal angioplasty for basilar artery stenosis. Mayo Clin Proc 55:673-680, 1980

39. Terada T2, Higashida RT, Halbach VV, Det al: Transluminal angioplasty for arteriosclerotic disease of the distal vertebral and basilar arteries. J Neurol Neurosurg Psychiatry 60:377-381, 1996

40. Terada T1, Yokote H, Tsuura M, et al: Tissue plasminogen activator thrombolysis and transluminal angioplasty in the treatment of basilar artery thrombosis: case report. Surg Neurol 41:358-361, 1994

41. Theron JG, Payelle GG, Coskun O, Huet HF, et al: Carotid artery stenosis: treatment with protected balloon angioplasty and stent placement. Radiology 201:627-636, 1996

42. Touho H: Percutaneous transluminal angioplasty in the treatment of atherosclerotic disease of the anterior cerebral circulation and hemodynamic evaluation. J Neurosurg 82:953-980, 1995

43. Touho H, Ohnishi H, Karasawa J, et al: Percutaneous transluminal angioplasty for acute stroke due to stenosis of major cerebral vessels: report of two cases. Surg Neurol 41:362-367, 1994

44. Touho H, Ohnishi H, Seno M, et al: Percutaneous transluminal angioplasty of stenotic primitive hypoglossal artery--case report. Neurol Med Chir 34:371-374, 1994

45. Tsai FY, Berberian B, Matovich V, et al: Percutaneous transluminal angioplasty adjunct to thrombolysis for acute middle cerebral artery rethrombosis. AJNR 15:1823-1829, 1994

46. Tsai FY1, Matovich V, Hieshima G, et al: Percutaneous transluminal angioplasty of the carotid artery. AJNR 7:349-358, 1986

47. Weksler BB, Lewin M: Anticoagulation in cerebral ischemia. Stroke 14:658-663, 1983

48. Zollikofer CL, Salomonowitz E, Sibley R, et al: Transluminal angioplasty evaluated by electron microscopy. Radiology 153:369-374, 1984

Manuscript received August 21, 1998.

Accepted in final form September 8, 1998. 
Address reprint requests to: Elisabeth Berg-Dammer, M.D., Klinik für Neurologie mit Klinischer Neurophysiologie, Alfried Krupp Krankenhaus, Alfried Krupp Straße 21,D-45117 Essen, Germany. 